\title{
The utility of Bambusoideae (Poaceae, Poales) leaf blade anatomy for identification and systematics
}

\author{
T. D. Leandro ${ }^{*}$, R. T. Shirasuna ${ }^{b}$, T. S. Filgueiras ${ }^{b}$ and V. L. Scatena ${ }^{a}$ \\ aDepartamento de Botânica, Universidade Estadual Paulista - UNESP, Av. 24A, 1515, Bela Vista, \\ CEP 13506-900, Rio Claro, SP, Brazil \\ 'Instituto de Botânica, CP 68041, CEP 04045-972, São Paulo, SP, Brazil \\ *e-mail: thaleshdias@gmail.com
}

Received: January 28, 2015 - Accepted: July 1, 2015 - Distributed: August 31, 2016

(With 2 figures)

\begin{abstract}
Bambusoideae is a diverse subfamily that includes herbaceous (Olyreae) and woody (Arundinarieae and Bambuseae) bamboos. Species within Bambusae are particularly difficult to identify due to their monocarpic lifecycle and the often long durations between mass flowering events; whereas the herbaceous bamboos are pluricarpic, but often are found with no reproductive structures. The leaf blade anatomy of 16 sympatric species of native Brazilian bamboos (Olyreae and Bambuseae) from the Atlantic Rainforest was studied in order to detect useful features for their identification. All the studied species share the following features: epidermis with a single stratum of cells; adaxial bulliform cells; mesophyll with arm cells, rosette cells, and fusoid cells; and collateral vascular bundles. Herbaceous bamboos share two features: papillae scattered on the abaxial surface and parallel-sided arrays of bulliform cells; whereas woody bamboos share: centrally organized papillae and fan-shaped arrays of bulliform cells. Also within the woody bamboos, intercostal fibers and a midrib with only one vascular bundle (simple midrib) characterize the subtribe Arthrostylidiinae; whereas a midrib with more than one vascular bundle (complex midrib) and a stomatal apparatus with two pappilae per subsidiary cell characterize the subtribe Chusqueinae. There are also diagnostic features for the sampled species, such as: papillae shape, and the outline and structure of the midrib. An identification key for all the studied species is provided based on the anatomical features.
\end{abstract}

Keywords: Arthrostylidiinae, Bambuseae, Chusqueinae, leaf blade, Olyreae.

\section{A utilidade da anatomia da lâmina foliar para a identificação e sistemática de espécies de Bambuboideae (Poaceae, Poales)}

\section{Resumo}

Bambusoideae é uma subfamília que inclui diversas espécies de bambus herbáceos (Olyreae) e lignificados (Arundinarie e Bambuseae). Bambus lignificados geralmente apresentam dificuldades de delimitação e identificação, devido principalmente ao ciclo monocárpico e longa amplitude temporal entre florações; enquanto que bambus herbáceos possuem ciclo pluricárpico, porém frequentemente são encontrados em estágio vegetativo. Foi estudada a anatomia da lâmina foliar de 16 espécies de Bambusoideae (Olyreae e Bambuseae), simpátricas e nativas do Brasil, visando levantar caracteres úteis para sua identificação. Todos os táxons estudados compartilham: epiderme uniestratificada; células buliformes na face adaxial; mesofilo com células invaginantes, células em roseta e células fusoides; e feixes vasculares colaterais. Bambus herbáceos compartilham: papilas dispersas na face abaxial e grupos de células buliformes organizadas paralelamente; enquanto que bambos lignificados compartilham: papilas organizadas em colunas centrais e grupos de células buliformes em forma de leque. Ainda dentre os bambus lignificados, fibras intercostais e nervura central com apenas um feixe vascular (nervura central simples) caracterizam a subtribo Arthrostylidiinae; enquanto que nervura central com mais de um feixe vascular (nervura central complexa) e aparelho estomático com duas papilas por célula subsidiária caracterizam a subtribo Chusqueinae. Há ainda caracteres anatômicos diagnósticos, tais como: forma da papila, e forma e estrutura da nervura central. Uma chave de identificação é fornecida baseada nos caracteres anatômicos relevantes à identificação das espécies estudadas.

Palavras-chave: Arthrostylidiinae, Bambuseae, Chusqueinae, lâmina foliar, Olyreae. 


\section{Introduction}

The cosmopolitan family Poaceae comprise about 11,000 species found mainly in grasslands and forest formations (Watson and Dallwitz, 1992 onwards; GPWG II, 2012). Twelve subfamilies are recognized within Poaceae (GPWG II, 2012; Soreng et al., 2015), among them Bambusoideae, a monophyletic group that currently includes 1,482 described species (Clark et al., 2015). Three Bambusoideae tribes are recognized, two of which are found in the Neotropics: Bambuseae, which comprise the woody bamboos; and Olyreae, the herbaceous bamboos (Kelchner, 2013; Clark et al., 2015). The Atlantic Rainforest is considered an important center of bamboo diversity (Judziewicz et al., 1999), and Brazil occupies a leading position based on number of species (298) and high endemism (172) (Carvalho et al., 2016).

Bambusoideae may be distinguished from other grass subfamilies by morphological, anatomical, and ecological characters. Monocarpic perennial lifecycle, lignified culms, branching nodes, pseudopetiolate leaves, and an outer ligule are characters worth mentioning for the woody bamboos (GPWG, 2001; BPG, 2012); whereas herbaceous bamboos are pluricarpic, usually unbranched, with quite weak culms and an inner ligule (Judziewicz et al., 1999). Together with, the strongly and asymmetrically invaginated arm cells as seen in cross section are highly important for the recognition of Bambusoideae species (GPWG, 2001), and also represents one of the main synapomorphies for this group (Zhang and Clark, 2000; BPG, 2012).

In general, the Poaceae taxonomy is mainly based on reproductive characters, such as the shape and structure of spikelets and inflorescence types (Longhi-Wagner, 2012). This is true more particularly for the herbaceous species, which generally bloom many times in their life cycle. In contrast, the woody bamboos bloom only once during a life cycle (Janzen, 1976; Filgueiras, 1988), and sometimes even herbaceous species are found with no reproductive structures. For this reason, searching for vegetative characters in addition to the reproductive ones is highly important to aid in species identification, and anatomical features often have provided useful findings (e.g. Brandis, 1907; Prat, 1936; Brown, 1958; Metcalfe, 1960; Calderón and Soderstrom, 1973; Renvoize, 1987; Vieira et al., 2002; Guglieri et al., 2008; Oliveira et al., 2008; Pelegrin et al., 2009; Jesus Junior et al., 2012; Viana et al., 2013a, b; Leandro et al., 2016; Aliscioni et al., 2016).

Considering that mostly bamboo plants have unique life cycles, but also the importance of the leaf blade anatomy for the taxonomy of grasses in general, we studied 16 sympatric species of native bamboos from the Atlantic Rainforest. We examined the leaf blade anatomy of three species of herbaceous bamboos and 13 species of woody bamboos in order to provide useful features for their identification.

\section{Material and Methods}

\subsection{Sampling area}

The study was carried out with 16 native species sampled at Parque Estadual das Fontes do Ipiranga PEFI (23 $28^{\circ} " 08^{\prime \prime} \mathrm{S}$ and $23^{\circ} 40^{\prime} 18^{\prime \prime} \mathrm{S}-46^{\circ} 36^{\prime} 48^{\prime \prime} \mathrm{W}$ and $46^{\circ} 38^{\prime} 00^{\prime}$ 'W) [Ipiranga State Park], a fragment of Atlantic Rainforest located in the State of São Paulo, Brazil. We have analysed three specimens per species, but only one voucher per specimens was included in the herbarium of the Instituto de Botânica (SP) (Table 1). The choice of taxa was based on a floristic study of the area that indicated the necessity of providing additional data in order to aid in species identification and conservation (Shirasuna and Filgueiras, 2013). Olyra loretensis Mez was not included in this study due to its uncertain occurrence in the PEFI (see Shirasuna and Filgueiras, 2013 for details about each species).

\subsection{Anatomical analysis}

For the woody bamboos, mature leaf blades were taken from the branches at the mid-culm, whereas for the herbaceous bamboos mature leaves were taken from the third node from the base. Fresh plant material was fixed in FAA $_{50}$ (Johansen, 1940) and later stored in 70\% ethanol. Found on leaves of Arthrostylidiinae species, the green stripe was excluded from this work due to its anatomical peculiarities in relation to the remainder of the leaf blade (Judziewicz et al., 1999).

Samples from the middle portion of the leaf blade were embedded in polyethylene glycol 1500 solution (adapted from Richter, 1985) and cross-sectioned with a rotary microtome. Sections were cleared in sodium hypochlorite $50 \%$, washed in distilled water, stained with Astra blue and Safranin (Bukatsh, 1972), and finally mounted on semi-permanent slides with glycerol. Also, a maceration technique was performed by the Jeffrey's method (Johansen, $1940)$ in order to describe the epidermal features.

Descriptions were primarily based on Ellis (1976, 1979), and optical images were obtained on a Leica DM4000B microscope using the software Leica Application Suite LASV4.0.

\section{Results}

\subsection{Surface view}

All the studied taxa share an epidermis with long-short cell alternation (Figures 1A-M). Short cells occur as silica bodies (Figures 1D, F, K - arrow) or suberized cells (cork cells - arrowhead) (Figure 1A) - sometimes as silico-suberose couples in the intercostal zone (e.g. Figure 1A). The wall sinuosity of long cells may be deep (Figures 1B, E, K), moderate (Figures 1A, F) or slight (Figures 1G, J). Papillae commonly occur on the abaxial surface: less pronounced in the herbaceous species (e.g. Figure 1D) and more pronounced in the woody species (e.g. Figures 1C, H). In Merostachys argyronema Lindm. papillae are very conspicuous (Figure 1H; Table 2), and in Merostachys 
Table 1. Specimens used in this study, with classification and voucher information provided.

\begin{tabular}{|c|c|}
\hline Taxa and classification & Voucher information \\
\hline \multicolumn{2}{|l|}{ TRIBE OLYREAE } \\
\hline \multicolumn{2}{|l|}{ Subtribe Olyrinae } \\
\hline Olyra glaberrima Raddi & A. Custodio Filho 124 (SP 160961) \\
\hline O. humilis Nees & R. T. Shirasuna 2617 (SP 415204) \\
\hline Parodiolyra micrantha (Kunth) Davidse \& Zuloaga & R. T. Shirasuna 2863 (SP 420323) \\
\hline \multicolumn{2}{|l|}{ TRIBE BAMBUSEAE } \\
\hline \multicolumn{2}{|l|}{ Subtribe Chusqueinae } \\
\hline Chusquea bambusoides (Raddi) Hack. & R. T. Shirasuna \& A. Costa 1809 (SP 409031) \\
\hline C. capituliflora Trin var. pubescens McClure \& L.B. Sm. & R. T. Shirasuna 2760 (SP 415735) \\
\hline C. meyeriana Rupr. ex Doell & R. T. Shirasuna 2697 (SP 415247) \\
\hline \multicolumn{2}{|l|}{ Subtribe Arthrostylidiinae } \\
\hline Aulonemia aristulata (Doell) McClure & R. T. Shirasuna 2860 (SP 420320) \\
\hline Merostachys argyronema Lindm. & R. T. Shirasuna 2868 (SP 420326) \\
\hline M. burmanii Send. & J. F. Toledo s/no (SP 238492) \\
\hline M. magellanica Send. & M. T. Grombone s/nº (SP 412132) \\
\hline M. neesii Rupr. & R. T. Shirasuna 2864 (SP 430324) \\
\hline M. pluriflora Munro ex. E.G. Camus & R. T. Shirasuna 1811 (SP 409023) \\
\hline M. riedeliana Rupr. ex Doell & R. T. Shirasuna 2872 (SP 426233) \\
\hline M. scandens Send. & R. T. Shirasuna 2993 (SP 441817) \\
\hline M. skvortzovii Send. & T. Sendulsky 1318 (SP 166796) \\
\hline M. speciosa Spreng. & R. T. Shirasuna 2798 (SP 417980) \\
\hline
\end{tabular}

neesii Rupr. they have a concave apex (Figure 1C; Table 2). A scattered distribution of papillae is observed in the herbaceous bamboos (e.g. Figure 1D; Table 2), whereas the organization in the woody bamboos is often in a single central row (e.g. Figures $1 \mathrm{G}, \mathrm{I})$, but may be variable in some intercostal cells (1-2 rows) (e.g. Figure $1 \mathrm{H})$.

Trichomes mainly occur on the abaxial surface and they may be of three types: (i) prickle hairs (short and silicified, microscopic unicellular) (Figures 1C, F); (ii) macrohairs (macroscopic unicellular) (Figures 1E); (iii) or microhairs (microscopic bicellular) (Figures 1E, L, M). The occurrence of these trichomes is variable among the studied species and only Chusquea capituliflora Trin var. pubescens McClure \& L.B. Sm. has all the three types (Figures 1E, F). Prickle hairs of most of the species develop an enlarged base, usually as seen in Chusquea capituliflora var. pubescens (Figure $1 \mathrm{~F}$ ), but in $M$. neesii this base is more pronounced (Figure 1C). Macrohairs occur on the abaxial surface of C. capituliflora var. pubescens (Figure 1F) and Chusquea meyeriana Rupr. ex Doell (Figure 1I - scars). Bicellular microhairs often consist of cells of about the same size (e.g. Figure 1M), except for C. capituliflora var. pubescens, in which the apical cell is reduced (Figure 1L). Microhairs often occur on the abaxial surface in the woody species and Parodiolyra micrantha (Kunth) Davidse \& Zuloaga.

Stomata are paracytic and occur on the abaxial surface of all the studied species, but also on the adaxial surface in A. aristulata and Olyra humilis Nees (Figure 1B; Table 2). Stomatal apparatus comprise triangular subsidiary cells (Figures 1B, D, H, K) or semi-circular (cupuliform) cells
(Figures 1A, E, G). In species of Chusquea the stomatal apparatus bears two papillae per subsidiary cell as seen in Chusquea capituliflora var. pubescens (Figure 1E detail inset; Table 2).

\subsection{Cross section}

The epidermis consists of a single stratum of cells with slightly thickened outer walls (Figures 2A-Q). Epidermal cells are visually about the same size (Figures 2E, G, J), but may be larger on the adaxial side (Figures 2F, H, M) excluding the bulliform cells. Bulliform cells occur as part of the adaxial epidermis (Figures 2D-M) and form a fanshaped array in the woody bamboos, (e.g. Figures $2 \mathrm{G}, \mathrm{J}, \mathrm{K}$; Table 2); whereas the herbaceous bamboos share a parallelsided array of bulliform cells (e.g. Figures 2E, I; Table 2).

The mesophyll comprise arm cells, fusoid cells, rosette cells, fibers, and vascular bundles. Asymmetrically invaginated arm cells are parallel to the epidermis (Figures 2E-M), including the midrib portion (Figures 2A-D). Herbaceous species (Figures 2E, I) and Chusquea bambusoides (Figure 2H) develop arm cells with invaginations only from the abaxial side, whereas the other species develop invaginations from both sides (Figures 2F, G, J-M). The number of rosette cells between each fusoid cell is often variable (one to four) within the same sample/specimen (Figures 2E-M). Fusoid cells occur adjacent to the vascular bundles and arm cells (Figures 2E-M); and their outline may be short and wide, as seen in A. aristulata (Figure 2G), or long and narrow, as in $M$. neesii (Figure 2F). Intercostal fibers located adjacent to the bulliform cells (sometimes also opposite) occur just 


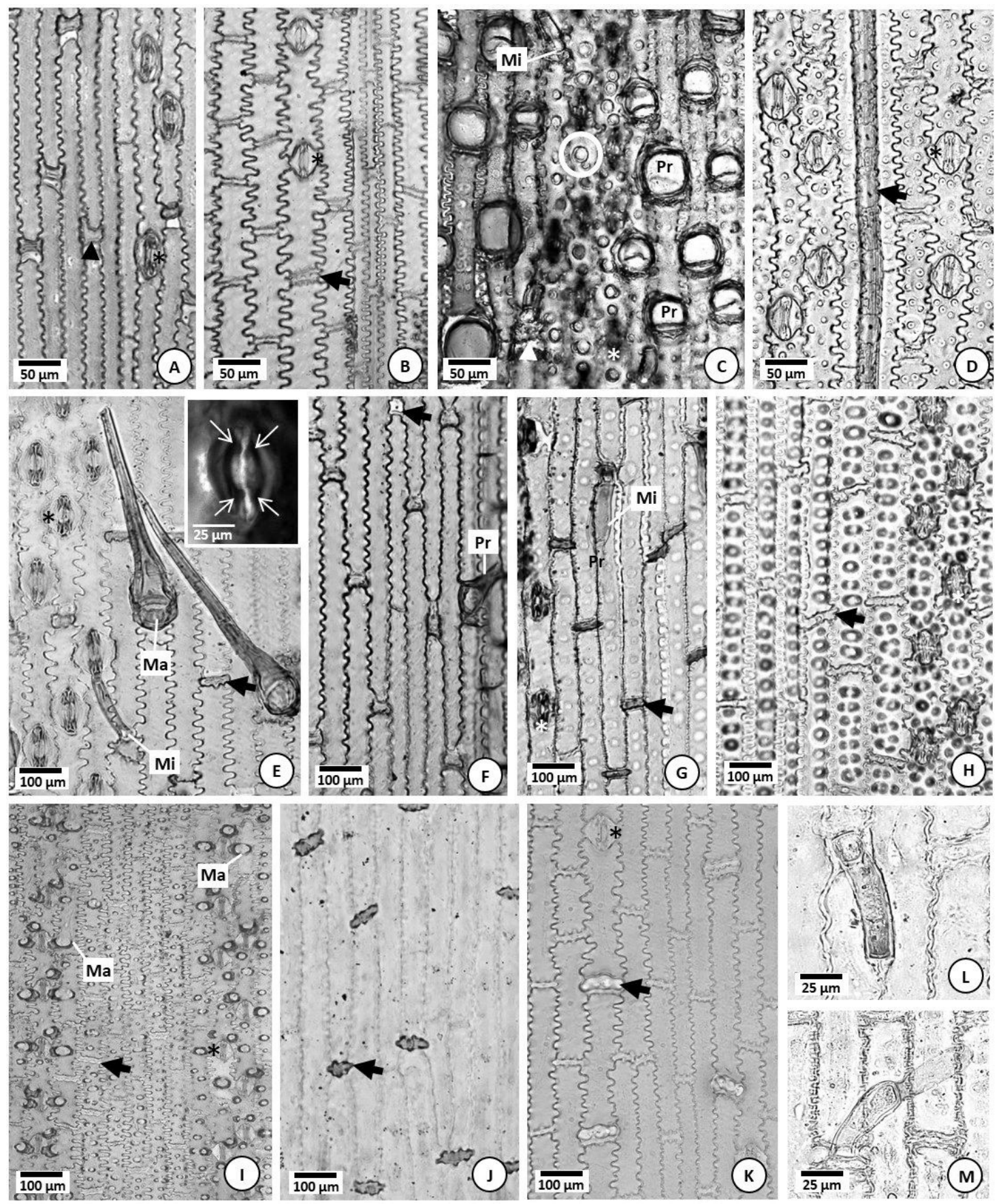

Figure 1. Surface view of leaf blades of Bambusoideae species. Adaxial surface (B, F, K) and abaxial surface (A, C-E, G-J). (A) Chusquea bambusoides with cupuliform subsidiary cells (*) and silico-suberose couples; (B) Olyra humilis with triangular subsidiary cells $(*)$; (C) Merostachys neesii showing papillae with concave apex (white circle); (D) Olyra glaberrima with silica body (black arrow) and papillae scattered; (E) Chusquea capituliflora var. pubescens with macrohairs (Ma), microhairs (Mi), and a detail showing the stomata apparatus bearing two papillae per subsidiary cell (white arrows); (F) Chusquea capituliflora var. pubescens with prickle (Pr); (G) Aulonemia aristulata with microhair (Mi); (H) Merostachys argyronema with papillae organized in a central row (or double row in some long cells); (I) Chusquea meyeriana showing the epidermis with macrohair scars (Ma); (J) Merostachys riedeliana with silica body (black arrow); (K) Parodiolyra micrantha showing silica body (black arrow); (L) Chusquea capituliflora var. pubescens detail of a bicellular trichome (microhair) with reduced apical cell; (M) Aulonemia aristulata detail of a bicellular trichome (microhair) with cells about the same size. (Ma) macrohair; (Mi) microhair; (Pr) prickles. Black arrows: silica bodies; white arrows: papillae; arrowhead: suberized cells; asterisks: stomata; white circle: papillae with concave apex. 
Table 2. Summary of leaf blade features useful for delimiting the tribes and subtribes, and also for recognizing the species.

\section{SPECIES}

\begin{tabular}{|c|c|c|c|c|c|c|c|c|c|c|c|c|c|c|c|c|}
\hline \multirow[b]{3}{*}{ FEATURES } & \multirow{2}{*}{\multicolumn{3}{|c|}{$\begin{array}{c}\text { Olyreae } \\
\text { herbaceous } \\
\text { bamboos } \\
\text { Olyrinae }\end{array}$}} & \multicolumn{13}{|c|}{$\begin{array}{l}\text { Bambuseae } \\
\text { woody bamboos }\end{array}$} \\
\hline & & & & \multicolumn{3}{|c|}{ Chusqueinae } & \multicolumn{10}{|c|}{ Arthrostylidiinae } \\
\hline & 1 & 2 & 3 & 4 & 5 & 6 & 7 & 8 & 9 & 10 & 11 & 12 & 13 & 14 & 15 & 16 \\
\hline \multicolumn{17}{|l|}{ Epidermis } \\
\hline $\begin{array}{l}\text { Papillae scattered on the abaxial } \\
\text { surface }\end{array}$ & + & + & + & - & - & - & - & - & - & - & - & - & - & - & - & - \\
\hline $\begin{array}{l}\text { Papillae centrally organized in a } \\
\text { single or double row }\end{array}$ & - & - & - & + & + & + & + & + & + & + & + & + & + & + & + & + \\
\hline Papillae with concave apex & - & - & - & - & - & - & - & - & - & - & + & - & - & - & - & - \\
\hline Papillae (two) per subsidiary cell & - & - & - & + & + & + & - & - & - & - & - & - & - & - & - & - \\
\hline Microhairs with reduced apical cell & - & - & - & - & + & - & - & - & - & - & - & - & - & - & - & - \\
\hline Amphistomatic leaves & + & - & - & - & - & - & + & - & - & - & - & - & - & - & - & - \\
\hline \multicolumn{17}{|l|}{ Mesophyll } \\
\hline Parallel-sided arrays of bulliform cells & + & + & + & - & - & - & - & - & - & - & - & - & - & - & - & - \\
\hline Fan-shaped arrays of bulliform cells & - & - & - & + & + & + & + & + & + & + & + & + & + & + & + & + \\
\hline Intercostal fibers & - & - & - & - & - & - & + & + & + & + & + & + & + & + & + & + \\
\hline \multicolumn{17}{|l|}{ Midrib } \\
\hline Adaxially projected & - & - & + & - & - & - & - & - & - & - & - & - & - & - & - & - \\
\hline Complex midrib & - & - & - & + & + & + & - & - & - & - & - & - & - & - & - & - \\
\hline Simple midrib & + & + & + & - & - & - & + & + & + & + & + & + & + & + & + & + \\
\hline $\begin{array}{l}\text { With one vascular bundle opposite } \\
\text { to the central one }\end{array}$ & - & - & - & - & + & - & - & - & - & - & - & - & - & - & - & - \\
\hline
\end{tabular}

1. Olyra humilis; 2. O. glaberrima; 3. Parodiolyra micrantha; 4. Chusquea bambusoides; 5. C. capituliflora var. pubescens; 6. C. meyeriana; 7. Aulonemia aristulata; 8. Merostachys argyronema; 9. M. burmanii; 10. M. magellanica; 11. M. neesii; 12. M. pluriflora; 13. M. riedeliana; 14. M. scandens; 15. M. skvortzovii; 16. M. speciosa. (+) presence, $(-)$ absence.

among species of Arthrostylidiinae (e.g. Figures 2D, F, G; Table 2). Collateral vascular bundles are surrounded by a double sheath (Figures $2 \mathrm{~A}-\mathrm{M}$ ): the outer one is parenchymatic and may be interrupted by fibers from both sides, as seen in Merostachys speciosa Spreng. (Figure 2M) or only from the abaxial side, as in Merostachys skvortzovii Send. (Figure 2L); and the inner one is pericyclic (mestome) with thick-walled cells (Figures 2A-M). First and third order vascular bundles are observed in all the studied species (Figures 2F-M).

In most of the studied species the midrib is flat (e.g. Figure 2D), but it is abaxially projected in species of Chusquea (Figures 2A, B) and adaxially projected in Padoriolyra micrantha (Figure 2C; Table 2). The midrib comprise one first order vascular bundle (Figures 2C, D), except among species of Chusquea, in which the midrib includes minor vascular bundles adjacent to the central one (Figures 2A, B; Table 2).

With regard to the margin, the leaf blade may be acute (Figure 2N-P) or obtuse (Figures 2Q); always with thickwalled epidermal cells and fibers immediately subjacent to the epidermis (e.g. Figures 2N-Q).

\subsection{Taxonomic treatment}

The main anatomical features are summarized in Table 2. These data in tabular form are available upon request from the first author.

Identification key to the native Bambusoideae species from PEFI, SP, based on the leaf blade anatomical data (surface view and cross section):

1. Papillae scattered on the abaxial surface; parallel-sided arrays of bulliform cells (Tribe Olyreae)

2. Prickle hairs on the abaxial surface developed; midrib adaxially projected Parodiolyra micrantha

2'. Prickle hairs on the abaxial surface lacking; midrib slightly convex on both surfaces

3. Leaves amphistomatic; adaxial epidermal cells larger than abaxial epidermal cells (excluding the bulliform cells)

Olyra humilis

3'. Leaves hypostomatic; adaxial epidermal cells equal to sub-equal to the abaxial epidermal cells (excluding the bulliform cells) Olyra glaberrima 
1'Papillae centrally organized in a single or double row on the abaxial surface; fan-shaped arrays of bulliform cells (Tribe Bambuseae)

4. Intercostal fibers developed; midrib with only one vascular bundle (simple midrib); stomata apparatus without papillae (Subtribe Arthrostylidiinae)

5. Stomata on both surfaces; papillae on the adaxial surface developed Aulonemia aristulata

5'. Stomata only on the abaxial surface; papillae on the adaxial surface lacking

6. Central vascular bundle in the midrib (major one) with outer sheath interrupted by fibers from both sides

7. First order vascular bundle with outer sheath interrupted by fibers from the abaxial side ...... Merostachys scandens

7'. Fisrt order vascular bundle with outer sheath interrupted by fibers from both sides

8. Fusoid cells long and narrow... Merostachys magellanica

8'. Fusoid cells short and wide

9. Adaxial epidermal cells larger than abaxial epidermal cells (excluding the bulliform cells) .... Merostachys riedeliana

9'. Adaxial epidermal cells equal to sub-equal to the abaxial epidermal cells (excluding the bulliform cells)

10. Prickle hairs on the abaxial surface developed Merostachys burmanii

10'. Prickle hairs on the abaxial surface lacking Merostachys pluriflora

6'. Central vascular bundle in the midrib (major one) with outer sheath interrupted by fibers only from the abaxial side

11. First order vascular vascular bundle with outer sheath interrupted by fibers from both sides

12. Bicellular microhairs on the adaxial surface developed; adaxial epidermal cells larger than abaxial epidermal cells (excluding the bulliform cells) ....... Merostachys neesii

12'. Bicellular microhairs on the adaxial surface lacking; adaxial epidermal cells equal to sub-equal to the abaxial epidermal cells (excluding the bulliform cells) Merostachys skvortzovii

11'. First order vascular vascular bundle with outer sheath interrupted by fibers only from the abaxial side

13. Fusoid cells short and wide; bicellular microhairs on the adaxial surface developed ...... Merostachys argyronema

13'. Fusoid cells long and narrow; bicellular microhairs on the adaxial surface lacking ........... Merostachys speciosa

4'. Intercostal fibers lacking; midrib with more than one vascular bundle (complex midrib); stomatal apparatus bearing two papillae per subsidiary cell (Subtribe Chusqueinae)
14. Midrib with two vascular bundles subjacent to the adaxial epidermis and opposite to the central one Chusquea meyeriana

14'. Midrib with one vascular bundle subjacent to the adaxial epidermis and opposite to the central one

15. Prickle hairs on the adaxial surface developed; macrohairs on the abaxial surface developed; bicellular microhairs developed

Chusquea capituliflora var. pubescens

15'. Prickle hairs on the adaxial surface lacking, macrohairs on the abaxial surface lacking; bicellular microhairs lacking Chusquea bambusoides

\section{Discussion}

Our anatomical study demonstrates that papillae scattered on the abaxial surface and parallel-sided arrays of bulliform cells are exclusive features among the herbaceous bamboos sampled; whereas centrally organized papillae and fan-shaped arrays of bulliform cells are exclusive features among the woody bamboos sampled.

Within the herbaceous bamboos sampled, the midrib outline and amphistomatic leaves may distinguish Parodiolyra Soderstr. \& Zuloaga from Olyra L. Although this may be true, it is not clear if these features are consistent among all Brazilian species of Olyra (20) and Parodiolyra (four) (Oliveira and Filgueiras, 2016a, b). Comparatively, within the woody bamboos sampled, intercostal fibers and a midrib with only one vascular bundle (simple midrib) characterize the subtribe Arthrostylidiinae; whereas a stomata apparatus bearing two papillae per subsidiary cell and a midrib with more than one vascular bundle (complex midrib) characterize the subtribe Chusqueinae. The presence of two papillae per subsidiary cell herein supports the assumption of this feature as a synapomorphy for Chusquea (Fisher et al., 2009, 2014), although there are not enough studies on micromorphology and anatomy to clarify its value. Currently, the set of features herein observed for Arthrostylidiinae and Chusqueinae is common among all species known within each subtribe and extremely applicable for recognizing these groups (BPG, 2012; Clark et al., 2015).

The comparative anatomical analysis herein performed demonstrates that the variation in the distribution of papillae is useful for delimiting tribes. There are some reports showing the importance of this feature in bamboo systematics (e.g. Soderstrom and Ellis, 1987; Paisooksantivatana and Pohl, 1992; Yang et al., 2008; Gomes and Neves, 2009; Mota, 2013), but also for other closely related groups (e.g. Pelegrin et al., 2009). Our study is not able to define the value of this feature to the systematics of Olyreae and Bambuseae, therefore a detailed work to evaluate both distribution and type of papillae within different groups would be informative.

Our study also indicates that some features may be considered diagnostic at the species level. Among them, the stomata on the adaxial surface in Aulonemia aristulata 

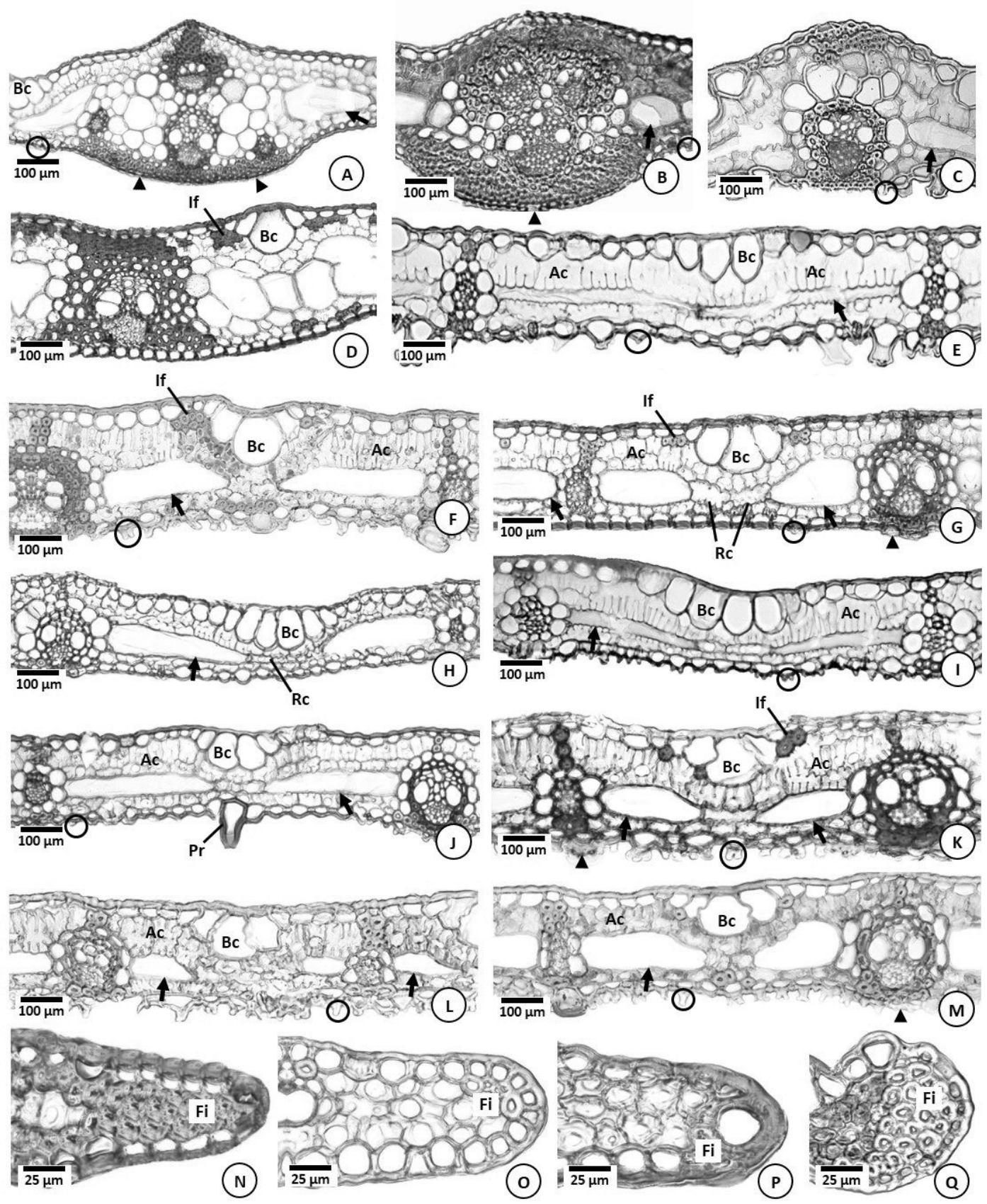

Figure 2. Cross section of leaf blades of Bambusoideae species. Midrib (A-D), mesophyll (E-M) and margin (N-Q). (A) Chusquea capituliflora var. pubescens showing complex midrib with one vascular bundle opposite to the central one; (B) Chusquea meyeriana showing complex midrib with two vascular bundles opposite to the central one; (C) Parodiolyra micrantha showing midrib with only one vascular bundle (simple midrib); (D) Aulonemia aristulata with intercostal fibers (If); (E) Olyra humilis showing arm cells with invaginations only from the abaxial side; (F) Merostachys neesii with intercostal fibers (If), bulliform cells (Bc) and arm cells (Ac); (G) Aulonemia aristulata showing arm cells with invaginations from both sides; (H) Chusquea bambusoides showing rosette cells (Rc); (I) Parodiolyra micrantha with papillae (black circle); (J) Chusquea capituliflora var. pubescens showing prickle hair (Pr); (K) Merostachys burmanii with silica body (arrowhead); (L) Merostachys skvortzovii showing vascular bundles with outer sheath interrupted by fibers from the abaxial side; (M) Merostachys speciosa showing vascular bundles surrounded by a double sheath; (N) Aulonemia aristulata with acute margin and thick-walled epidermal cells; (O) Chusquea capituliflora var. pubescens with acute margin and a few fibers; (P) Chusquea bambusoides with thick-walled epidermal cells; (Q) Chusquea meyeriana with obtuse margin and many fibers. (Ac) arm cells; (Bc) bulliform cells; (Fi) fibers; (If) intercostal fibers; (Pr) prickle hair; (Rc) rosette cells. Arrows: fusoid cells; arrowheads: silica bodies; black circles: papillae. 
must be mentioned, since their occurrence is considered as rare for Aulonemia (Arthrostylidiinae) (Viana et al., 2013a), but usually typical for species within the subtribe Guaduineae (Soderstrom and Ellis, 1987). Adaxial stomata were also recently observed in other species within Aulonemia (Viana, 2010; Viana et al., 2001), and thus it reinforces the anatomical affinity between the subtribes Arthrostylidiinae and Guaduineae (Bambuseae) (Soderstrom and Ellis, 1987; Zhang and Clark, 2000; Ruiz-Sanchéz et al., 2008), as well as the necessity of a broad anatomical study in order to elucidate the systematic value of this feature for Bambuseae.

It is important to highlight that the size and shape of bulliform cells may be influenced by environmental factors (Shields, 1951), but the structural variation herein observed deserves more attention in order to verify its constancy among bamboo groups. Also, the fusoid cell is another feature that requires additional attention since its environmentally influenced morpho-anatomical variations (March and Clark, 2011; T. D. Leandro, unpubl. data). In the present study, we consider the structure of bulliform cells and the outline of fusoid cells as relevant features for delimiting species given that all specimens were sampled under the same environmental conditions.

\section{Conclusion}

Although most of the information herein provided is not a novelty for Bambusoideae, our results reinforce the importance of leaf blade anatomy studies for grass systematics, specially when we consider the great number of questions that are still unclear. The inclusion of anatomical data as a routine on bamboo studies may be really useful for identifying diagnostic features and additional synapomorphies, in which certainly will aid in species circumscription.

\section{Acknowledgements}

This work was supported by the Conselho Nacional de Desenvolvimento Científico e Tecnológico - CNPq (Ph.D. grant to the first author - proc. 163550/2012-3 and Productivity in Research grant to the last author - proc. 301692/2010-6). To Fundação de Amparo à Pesquisa do Estado de São Paulo - FAPESP (proc. 2011/18275-0) and CNPq (proc. 471837/2011-3) also for the financial support. The authors are immensely grateful to Lynn G. Clark and Timothy J. Gallaher (EEOB, Iowa State University, U.S.A.) for their comments that greatly improved the manuscript.

\section{References}

ALISCIONI, S.S., OSPINA, J.C. and GOMIZ, N.E., 2016. Morphology and leaf anatomy of Setaria s.l. (Poaceae: Panicoideae: Paniceae) and its taxonomic significance. Plant Systematics and Evolution, vol. 302, no. 2, pp. 173-185. http://dx.doi.org/10.1007/ s00606-015-1251-9.
BAMBOO PHYLOGENY GROUP - BPG, 2012. An updated tribal and subtribal classification of the bamboos (Poaceae: Bambusoideae). Bamboo Science and Culture. The Journal of the American Bamboo Society, vol. 24, no. 1, pp. 1-10.

BRANDIS, D., 1907. V. Remarks on the structure of bamboo leaves. Transactions of the Linnean Society London Botany, vol. 7, no. 5, pp. 69-89. http://dx.doi.org/10.1111/j.1095-8339.1907. tb00152.x

BROWN, W.V., 1958. Leaf anatomy in grass systematics. Botanical Gazette, vol. 119, no. 3, pp. 170-178. http://dx.doi. org/10.1086/335974.

BUKATSH, F., 1972. Benerkemgem zeir Doppelfarbeing Astrablau-Safranina. Microkosmos, vol. 61, no. 8, pp. 255-256.

CALDERÓN, C.E. and SODERSTROM, T.R., 1973. Morphological and anatomical considerations of the grass subfamily Bambusoideae based on the new genus Maclurolyra. Smithsonian Contribuitions to Botany, vol. 11, no. 11, pp. 1-55. http://dx.doi.org/10.5479/ si.0081024X.11.

CARVALHO, M.L.S., DÓREA, M.C., FERREIRA, F.M., MOTA, A.C., DE OLIVEIRA, R.C., OLIVEIRA, R.P., FILGUEIRAS, T.S., REIS, P.A., SANTOS-GONÇALVES, A.P., SHIRASUNA, R.T., SILVA, A.S., VIANA, P.L., ZANIN, A. and LONGHI-WAGNER, H.M., 2016 [viewed 15 February 2016]. Bambusoideae. In: JARDIM BOTÂNICO DO RIO DE JANEIRO - JBRJ. Lista de espécies da flora do Brasil [online]. Rio de Janeiro. Available from: http://floradobrasil.jbrj.gov.br/jabot/floradobrasil/FB102232

CLARK, L.G., LONDOÑO, X. and RUIZ-SANCHEZ, E., 2015. Bamboo taxonomy and habitat. In: W. LIESE and M. KÖHL, eds. Bamboo: the plant and its uses. Cham: Springer International Publishing. p. 30. vol. 10.

ELLIS, R.P., 1976. A procedure for standardizing comparative leaf anatomy in the Poaceae. I. The leaf-blade as viewed in transverse section. Bothalia, vol. 12, no. 1, pp. 65-109. http:// dx.doi.org/10.4102/abc.v12i1.1382.

ELLIS, R.P., 1979. A procedure for standardizing comparative leaf anatomy in the Poaceae. II. The epidermis as seen in surface view. Bothalia, vol. 12, no. 4, pp. 65-109. http://dx.doi.org/10.4102/ abc.v12i4.1441.

FILGUEIRAS, T.S., 1988. A floração dos bambus e seu impacto ecológico. Eugeniana, vol. 15, pp. 1-8.

FISHER, A.E., CLARK, L.G. and KELCHNER, S.A., 2014. Molecular phylogeny estimation of the bamboo genus Chusquea (Poaceae: Bambusoideae: Bambuseae) and description of two new bamboo subgenera. Systematic Botany, vol. 39, no. 3, pp. 829-844. http://dx.doi.org/10.1600/036364414X681554.

FISHER, A.E., TRIPLETT, J.K., HO, C.-S., SCHILLER, A.D., OLTROGGE, K.A., SCHRODER, E.S., KELCHNER, S.A. and CLARK, L.G., 2009. Paraphyly in the bamboo subtribe Chusqueinae and a revised infrageneric classification for Chusquea. Systematic Botany, vol. 34, no. 4, pp. 673-683. http://dx.doi. org/10.1600/036364409790139790.

GOMES, D.M.S. and NEVES, L.J., 2009. Scanning electron microscopy of the leaf epidermis of Merostachys Spreng. (Poaceae: Bambusoideae). Acta Botanica Brasílica, vol. 23, no. 2, pp. 516-525. http://dx.doi.org/10.1590/S0102-33062009000200023.

GRASS PHYLOGENY WORKING GROUP - GPWG, 2001. Phylogeny and subfamilial classification of the grasses (Poaceae). Annals of the Missouri Botanical Garden, vol. 88, no. 3, pp. 373456. http://dx.doi.org/10.2307/3298585. 
GRASS PHYLOGENY WORKING GROUP II - GPWG II, 2012. New grass phylogeny resolves deep evolutionary relationships and discovers $\mathrm{C}_{4}$ origins. The New Phytologist, vol. 193, no. 2, pp. 304-312. http://dx.doi.org/10.1111/j.1469-8137.2011.03972.x. PMid:22115274

GUGLIERI, A., LONGHI-WAGNER, H.M. and ZULOAGA, F.O., 2008. Anatomia foliar das espécies de Panicum L. subg. Panicum (Poaceae: Panicoideae: Paniceae) no Brasil. Iheringia: Série Botânica, vol. 63, no. 2, pp. 279-293.

JANZEN, D.H., 1976. Why bamboos wait so long to flower. Annual Review of Ecology and Systematics, vol. 7, no. 1, pp. 347-391. http://dx.doi.org/10.1146/annurev.es.07.110176.002023.

JESUS-JUNIOR, L.A., OLIVEIRA, R.P., LEITE, K.R.B. and SILVA, L.B., 2012. Comparative analysis of the leaf anatomy in two Parodiolyra species (Poaceae: Olyreae) occuring on forests in Earstern Brazil. Brazilian Journal of Biology $=$ Revista Brasileira de Biologia, vol. 72, no. 1, pp. 205-210. http://dx.doi.org/10.1590/ S1519-69842012000100025. PMid:22437403.

JOHANSEN, D., 1940. Plant microtechnique. New York: McGrawn-Hill Book. 523 p.

JUDZIEWICZ, E.J., CLARK, L.G., LONDOÑO, X. and STERN, M.J., 1999. American bamboos. Washington: Smithsonian Institution Press. 392 p.

KELCHNER, S.A., 2013. Higher level phylogenetic relationships within the bamboos (Poaceae: Bambusoideae) based on five plastid markers. Molecular Phylogenetics and Evolution, vol. 67, no. 2, pp. 404-413. http://dx.doi.org/10.1016/j.ympev.2013.02.005. PMid:23454093.

LEANDRO, T.D., SCREMIN-DIAS, E. and ARRUDA, R.C.O., 2016. Micromorphology and anatomy of the leaf blade: a contribution to the taxonomy of Luziola (Poaceae, Oryzoideae) from the Pantanal, Brazil. Plant Systematics and Evolution, vol. 302, no. 3, pp. 265-273. http://dx.doi.org/10.1007/s00606-015-1260-8.

LONGHI-WAGNER, H.M., 2012. Poaceae: an overview with reference to Brazil. Rodriguésia, vol. 63, no. 1, pp. 89-100. http:// dx.doi.org/10.1590/S2175-78602012000100008.

MARCH, R.H. and CLARK, L.G., 2011. Sun-shade variation in bamboo (Poaceae: Bambusoideae) leaves. Telopea, vol. 13, no. 1-2, pp. 93-104. http://dx.doi.org/10.7751/telopea20116007.

METCALFE, R., 1960. Anatomy of the Monocotyledons I: Gramineae. Oxford: Claredon Press. 731 p.

MOTA, A.C.,2013. Sistemática de Chusquea subgênero Rettbergia (Bambusoideae, Poaceae). Feira de Santana: Universidade Estadual de Feira de Santana, 229 p. Ph.D. Thesis.

OLIVEIRA, R.P. and FILGUEIRAS, T.S., 2016a [viewed 15 February 2016]. Olyra. In: JARDIM BOTÂNICO DO RIO DE JANEIRO - JBRJ. Lista de espécies da flora do Brasil [online]. Rio de Janeiro. Available from: http://floradobrasil.jbrj.gov.br/ jabot/floradobrasil/FB13360

OLIVEIRA, R.P. and FILGUEIRAS, T.S., 2016b [viewed 15 February 2016]. Parodiolyra. In: JARDIM BOTÂNICO DO RIO DE JANEIRO - JBRJ. Lista de espécies da flora do Brasil [online]. Rio de Janeiro. Available from: http://floradobrasil.jbrj. gov.br/jabot/floradobrasil/FB13423

OLIVEIRA, R.P., LONGHI-WAGNER, H.M. and LEITE, K.R.B., 2008. A contribuição da anatomia foliar para a taxonomia de Raddia Bertol. (Poaceae: Bambusoideae). Acta Botanica
Brasílica, vol. 22, no. 1, pp. 1-19. http://dx.doi.org/10.1590/ S0102-33062008000100002.

PAISOOKSANTIVATANA, Y. and POHL, R.W., 1992. Morphology, anatomy and cytology of the genus Lithachne (Poaceae: Bambusoideae). Revista de Biologia Tropical, vol. 40, pp. 47-72.

PELEGRIN, C.M.G., LONGHI-WAGNER, H.M. and OLIVEIRA, P.L., 2009. Anatomia foliar como subsídio à taxonomia de espécies do Complexo Briza L. (Poaceae: Pooideae: Poeae). Acta Botanica Brasílica, vol. 23, no. 3, pp. 666-680. http://dx.doi.org/10.1590/ S0102-33062009000300006.

PRAT, H., 1936. La systemátique des Graminées. Annales des Sciences Naturelles Botanique, vol. 18, pp. 165-258.

RENVOIZE, S.A., 1987. A survey of leaf blade anatomy in grasses X. Bambuseae. Kew Bulletin, vol. 42, no. 1, pp. 201-207. http:// dx.doi.org/10.2307/4109902.

RICHTER, H.G., 1985. Wood and bark anatomy of Lauraceae II. Licaria Aublet. Iawa Bulletin, vol. 6, no. 3, pp. 187-199. http:// dx.doi.org/10.1163/22941932-90000938.

RUIZ-SANCHEZ, E., SOSA, V. and MEJÍA-SAULES, M.T., 2008. Phylogenetics of Otatea inferred from morphology and chloroplast DNA sequence data, and recircumscription of Guaduinae (Poaceae: Bambusoideae). Systematic Botany, vol. 33, no. 2, pp. 277-283. http://dx.doi.org/10.1600/036364408784571644.

SHIELDS, L.M., 1951. The involution mechanism in leaves of certain xeric grasses. Phytomorphology, vol. 1, no. 3-4, pp. 225-241.

SHIRASUNA, R.T. and FILGUEIRAS, T.S., 2013. Bambus nativos (Poaceae, Bambusoideae) no Parque Estadual das Fontes do Ipiranga, São Paulo, SP, Brasil. Hoehnea, vol. 40, no. 2, pp. 315-359. http://dx.doi.org/10.1590/S2236-89062013000200005.

SODERSTROM, T.R. and ELLIS, R.P., 1987. The position of bamboo genera and allies in a system of grass classification. In: T.R. SOLDERSTROM, K.W. HILU, C.S. CHAMPBELL and M.E. BARKWORTH, eds. Grass: systematics and evolution. Washington: Smithsonian Instituition Press, pp. 225-238.

SORENG, R.J., PETERSON, P.M., ROMASCHENKO, K., DAVIDSE, G., ZULOAGA, F.O., JUDZIEWICZ, E.J., FILGUEIRAS, T.S., DAVIS, J.I. and MORRONE, O., 2015. A worldwide phylogenetic classification of the Poaceae (Gramineae). Journal of Systematics and Evolution, vol. 53, no. 2, pp. 117-137. http://dx.doi.org/10.1111/jse.12150.

VIANA, P.L., 2010. O gênero Aulonemia Goudot (Poaceae: Bambusoideae: Bambuseae) no Brasil. Belo Horizonte: Universidade Federal de Minas Gerais, 272 p. PhD Thesis.

VIANA, P.L., FILGUEIRAS, T.S. and GRACIANO-RIBEIRO, D., 2013a. A new woody bamboo (Poaceae, Bambusoideae) from Central Brazil, Aulonemia xerophylla. Novon, vol. 22, no. 3, pp. 371-376. http://dx.doi.org/10.3417/2010044.

VIANA, P.L., FILGUEIRAS, T.S. and CLARK, L.G., 2013b. Cambajuva (Poaceae: Bambusoideae: Bambuseae: Arthrostylidiinae), a new woody bamboo genus from Southern Brazil. Systematic Botany, vol. 38, no. 1, pp. 97-103. http://dx.doi. org/10.1600/036364413X662097.

VIANA, P.L., FILGUEIRAS, T.S. and PAIVA, E.A.S., 2001. A new combination in Aulonemia (Poaceae: Bambusoideae: Bambuseae) based on floral analysis, anatomical features, and distribution. Brittonia, vol. 63, no. 1, pp. 102-112. http://dx.doi. org/10.1007/s12228-010-9138-0. 
VIEIRA, R.C., GOMES, D.M.S., SARAHYBA, L.S. and ARRUDA, R.C.O., 2002. Leaf anatomy of three herbaceous bamboo species. Brazilian Journal of Biology $=$ Revista Brasileira de Biologia, vol. 62, no. 4B, pp. 907-922. PMid:12659043.

WATSON, L. and DALLWITZ, M.J., 1992 [viewed 25 February 2016]. The grass genera of the world: descriptions, illustrations, identification, and information retrieval Version: 8 December 2015 [online]. Beijing: Institute of Botany. Available from: http:// delta-intkey.com
YANG, H., WANG, H. and LI, D., 2008. Comparative morphology of the foliage leaf epidermis, with emphasis on papillae characters, in key taxa of woody bamboos of the Asian tropics (Poaceae: Bambusoideae). Botanical Journal of the Linnean Society, vol. 156, no. 3, pp. 411-423. http://dx.doi.org/10.1111/j.10958339.2007.00736.x.

ZHANG, W. and CLARK, L.G., 2000. Phylogeny and classification of the Bambusoideae (Poaceae). In: S.W.L. JACOBS and J.E. EVERETT, eds. Grasses: systematics and evolution. Collingwood: CSIRO Publishing, pp. 35-42. 